\title{
Cerebral circulatory and metabolic effects of hypotension produced by deep halothane anaesthesia
}

\author{
N. P. KEANEY, V. W. PICKERODT, D. G. MCDOWALL, \\ N. J. CORONEOS, J. M. TURNER, AND Z. P. SHAH \\ From the Department of Anaesthesia, University of Leeds, Leeds
}

SUMMARY Hypotension to a mean blood pressure of $33 \mathrm{mmHg}$ for periods of 70 to 187 minutes was induced by increasing the inspired halothane concentration in 11 baboons which were already anaesthetized with $0.5 \%$ halothane, nitrous oxide, and oxygen. During hypotension, cerebral blood flow, measured by Xenon clearance and by a carotid electromagnetic flowmeter, decreased by more than half, and sagittal sinus oxygen saturation was $46 \%$. Cerebral oxygen uptake fell from $5 \cdot 15$ to $3.56 \mathrm{ml} . / 100 \mathrm{~g} / \mathrm{min}$ at this deeper level of halothane anaesthesia. Cerebral hyperaemia developed after hypotension in those animals which regained a mean blood pressure greater than $70 \mathrm{mmHg}$. Acidbase measurements on CSF from the cisterna magna revealed no metabolic acidosis during or after hypotension. In all four animals with intact autoregulation before hypotension, this was absent or impaired afterwards.

Controlled hypotension is used to diminish bleeding and to facilitate surgery. There is, however, a considerable disagreement about the safety of the technique; for example, Mayrhofer (1971) has written that: 'Induced hypotension, using ganglion-blocking drugs, should have been abandoned long ago as it is an unsafe and potentially dangerous technique', while Enderby (1972) has replied: 'We are today using this technique routinely and, moreover, have been doing so for more than 20 years'. When such divergent opinions are expressed, further investigation is indicated, and the present study was designed to elucidate the effect of controlled hypotension on cerebral blood flow, cerebral metabolism, and acid-base balance. Since it has been suggested (Nilsson and Siesjö, 1971) that hypotension with deep halothane anaesthesia may be safer than with other methods, because of the associated reduction in cerebral oxygen demand, it was decided to produce hypotension by this means in experimental animals.

\section{METHODS}

Eleven baboons were premedicated with phencyclidine $(0.8-1.0 \mathrm{mg} / \mathrm{kg})$ and anaesthesia was induced and maintained with halothane, nitrous oxide, and oxygen. After intramuscular injection of suxå methonium $(50 \mathrm{mg})$ an endotracheal tube was inserted and the animals were artificially ventilateg by a Palmer pump. Muscle relaxation was maie tained by injecting pancuronium $(1 \mathrm{mg})$ intramusct larly at half-hourly intervals. End-tidal $\mathrm{CO}_{2}$ was monitored by an infrared gas analyser and ventilation was adjusted to maintain normocapnia. Endtidal halothane was measured intermittently by an ultraviolet halothane meter. The inspired oxygen was adjusted so that $\mathrm{PaO}_{2}$ remained above 100 $\mathrm{mmHg}$. The temperature of the animal was kept at $37^{\circ} \mathrm{C}$ by automatically controlled heating lamps.

Not all measurements were made on all animals and the animals were divided into three experimental groups as indicated in Table 1. Cerebral blood flow (CBF) was measured by two independent methods: by the Xenon clearance technique and by an electromagnetic flowmeter. After exposure of the carotid artery bifurcation, a catheter for ${ }^{133}$ Xenon injection was inserted into a branch of the external carotid artery and directed centrally towards the bifurcation and all other branches of the external carotid artery were tied off. The scalp muscle was reflected and a collimated gamma detector was placed over the lateral aspect of the parietal bone and mounted in a coronal plane. CBF was calculated by exponential stripping of the Xenon clearance curve. Mean flow was derived from the values for grey and white matter flow together with the ratio of the two 
TABLE 1

EXPERIMENTAL PROCEDURES AND MEASUREMENTS ON THREE GROUPS OF BABOONS

\begin{tabular}{|c|c|c|c|c|c|c|c|}
\hline \multirow[t]{2}{*}{ Group } & \multirow[t]{2}{*}{ Expts. } & \multicolumn{2}{|c|}{ Cerebral blood flow } & \multirow{2}{*}{$\begin{array}{c}\text { Cerebral } \\
\text { oxygen } \\
\text { uptake } \\
\left(\mathrm{CMRO}_{2}\right)\end{array}$} & \multirow{2}{*}{$\begin{array}{c}\text { CSF pressure } \\
\text { and } \\
\text { acid-base } \\
\text { measurement }\end{array}$} & \multirow[t]{2}{*}{$E E G$} & \multirow{2}{*}{$\begin{array}{c}\text { Autoregulation } \\
\text { to noradrenaline } \\
\text { infusion }\end{array}$} \\
\hline & & $\begin{array}{c}\text { Carotid } \\
\text { electromagnetic } \\
\text { flow-probe }\end{array}$ & $\begin{array}{l}133 \text { Xenon } \\
\text { clearance }\end{array}$ & & & & \\
\hline I & $1-5$ & + & + & - & - & + & - \\
\hline II & $6-9$ & + & + & + & + & + & + \\
\hline III & $10-11$ & + & - & - & - & + & + \\
\hline
\end{tabular}

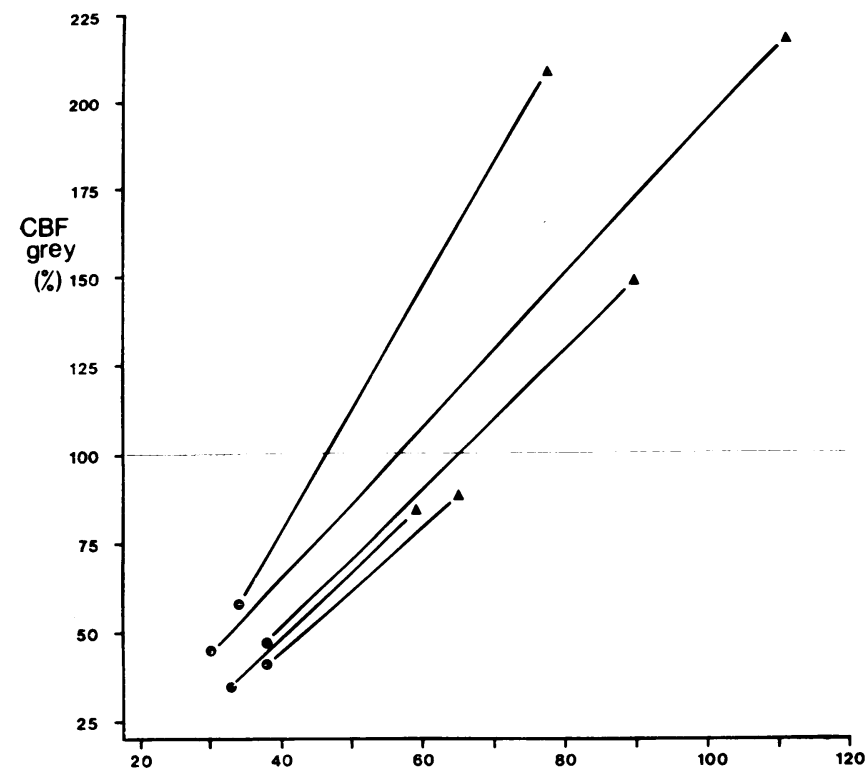

FIG. 1. Grey matter (CBF grey) and internal carotid (CarBF) blood flow during (O) and after $(\mathbf{\Delta})$ the period of hypotension expressed as a percentage of control $(100 \%)$ in the group 1 experiments.

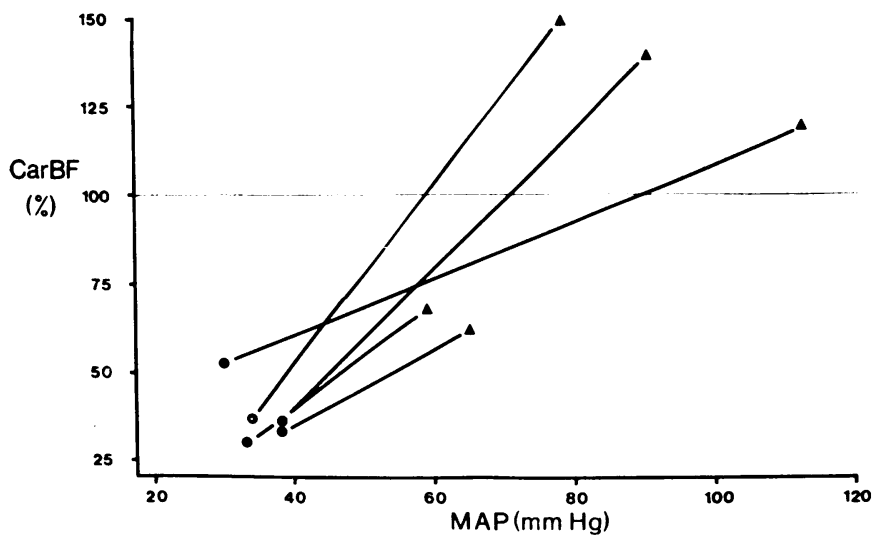


components of the clearance curve. An electromagnetic flow probe placed around the common carotid artery measured internal carotid blood flow (CarBF) continuously since the external carotid circulation had been ligated.

Catheters were also inserted into the sagittal sinus, cisterna magna, femoral artery and vein for measuring cerebral venous oxygen saturation and content, posterior fossa pressure and cerebrospinal fluid (CSF) $\mathrm{pH}$ and $\mathrm{PCO}_{2}$, arterial blood pressure and arterial $\mathrm{PO}_{2}, \mathrm{PCO}_{2}, \mathrm{pH}$, and oxygen saturation and content, and for administering intravenous normal saline ( $30 \mathrm{ml}$./hour). Samples of CSF were collected anaerobically in glass capillary tubes from the sealed catheter in the cisterna magna. All pressures were measured electronically and were recorded together with the CarBF and electroencephalogram (EEG). A transmittance oxygen saturation meter and conventional oxygen, $\mathrm{CO}_{2}$ and $\mathrm{pH}$ electrodes were used for the blood gas measurements. Oxygen content was also measured directly by a modification of the method described by Linden et al. (1965).

Cerebral oxygen uptake was calculated in three ways:

1. from the fast component of Xenon clearance ( $\mathrm{Fg})$ and arteriovenous oxygen content difference $\left(\mathrm{C}_{(\mathrm{a}-\mathrm{v})} \mathrm{O}_{2}\right)$ based on oxygen saturation $\left(\mathrm{SO}_{2}\right)$ measurements:

$$
\mathrm{C}_{(\mathrm{a}-\mathrm{v})} \mathrm{O}_{2}=\mathrm{S}_{(\mathrm{a}-\mathrm{v})} \mathrm{O}_{2} \times 1.34 \times \mathrm{Hb}
$$

$+0.3 \mathrm{ml} . / 100 \mathrm{mmHg} \mathrm{P}_{(\mathrm{a}-\mathrm{v})} \mathrm{O}_{2} / 100 \mathrm{ml}$. blood;

2. from $\mathrm{Fg}$ and $\mathrm{C}_{(\mathrm{a}-\mathrm{v})} \mathrm{O}_{2}$ obtained by direct oxygen content method; and

3. from mean $\mathrm{CBF}$ and $\mathrm{C}_{(\mathrm{a}-\mathrm{v})} \mathrm{O}_{2}$ based on $\mathrm{SO}_{2}$ measurements.

When surgical preparation was complete, the inspired halothane concentration was reduced to $0.5 \%$ and not less than one hour later control measurements were made. The inspired halothane concentration was then increased, causing the mean arterial blood pressure (MBP) to fall below $40 \mathrm{mmHg}$ over a 5 to 10 minute period. MBP was kept at this level for about two hours by adjusting the inspired halothane concentration and at the end of this period blood pressure was allowed to recover by reducing the inspired halothane. In the last six experiments autoregulation of the cerebral circulation to a rise of blood pressure was tested by infusing noradrenaline (NA) intravenously before and within an hour after deep halothane hypotension.

All results are expressed as mean $\pm \mathrm{SEM}$; probability values were obtained from paired $t$ tests.

\section{RESULTS}

The mean duration of halothane hypotension
TABLE 2

BLOOD GAS DATA FOR 11 BABOONS (MEANS \pm SEM)

\begin{tabular}{|c|c|c|c|}
\hline & \multicolumn{3}{|c|}{ Hypotension } \\
\hline & Before & During & After \\
\hline $\begin{array}{l}\mathrm{PO}_{2} \\
\mathrm{mmHg}\end{array}$ & $\begin{array}{r}119 \cdot 5 \\
\pm 5 \cdot 1\end{array}$ & $\begin{array}{l}131 \cdot 1^{*} \\
\pm 6 \cdot 2\end{array}$ & $\begin{array}{l}130 \cdot 8^{*} \\
\pm 5 \cdot 2\end{array}$ \\
\hline $\begin{array}{l}\mathrm{PCO}_{2} \\
\mathrm{mmHg}\end{array}$ & $\begin{array}{r}40 \cdot 8 \\
\pm 0 \cdot 8\end{array}$ & $\begin{array}{r}42 \cdot 1 \\
\pm 1 \cdot 5\end{array}$ & $\begin{array}{r}43 \cdot 0 \\
\pm 1 \cdot 2\end{array}$ \\
\hline $\mathrm{pH}$ & $\begin{aligned} & 7 \cdot 43 \\
\pm & 0 \cdot 003\end{aligned}$ & $\begin{array}{r}7 \cdot 39^{*} \\
\pm 0 \cdot 004\end{array}$ & $\begin{array}{r}7 \cdot 32^{*} \\
\pm 0 \cdot 017\end{array}$ \\
\hline $\begin{array}{l}\text { Standard bicarbonate } \\
\mathrm{mEq} / \mathrm{l} \text {. }\end{array}$ & $\begin{array}{r}23 \cdot 4 \\
\pm 1 \cdot 3\end{array}$ & $\begin{array}{l}20.9 \dagger \\
\pm 1.2\end{array}$ & $\begin{array}{l}16.6 \dagger \\
\pm 0.7\end{array}$ \\
\hline
\end{tabular}

* $\mathrm{P}<0.01$.

$\dagger \mathbf{P}<0.001$, derived from paired $t$ tests.

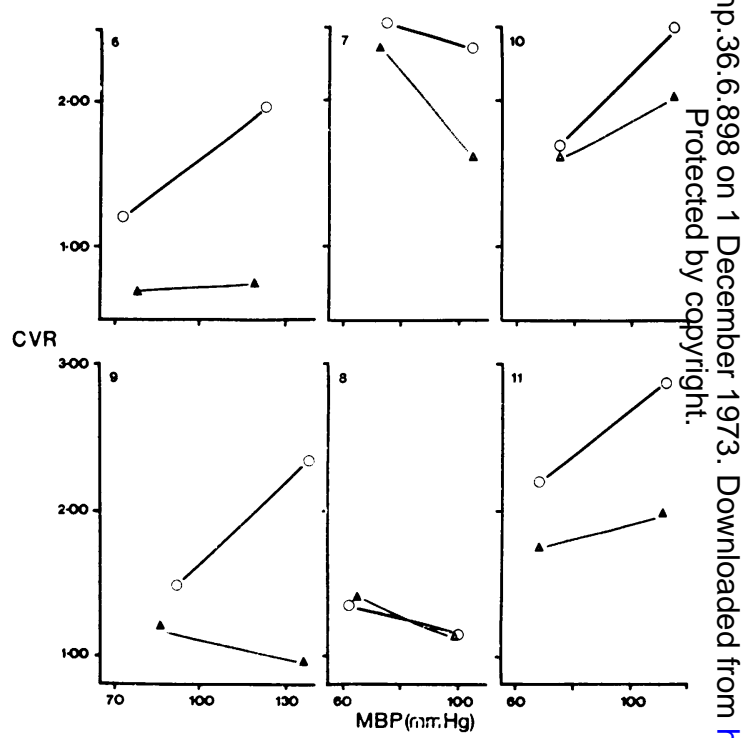

FIG. 2. Change of carotid vascular resistance (CVR) with blood pressure $(M B P)$ elevation before $(O-C)$ and after $(\mathbf{\Delta}-\mathbf{\Delta})$ the period of hypotension. Autoregulation judged to be present in baboons $6,9,10$, and 11 before and partial autoregulation in baboon 10 after (see Table 3).

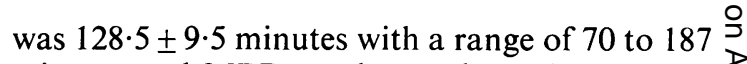
minutes and MBP was lowered to $40 \mathrm{mmHg}$ in $8 \cdot 2 \pm 1 \cdot 5$ minutes. During the control period MAP was $86 \pm 5 \mathrm{mmHg}$ and CarBF was 0 $45 \pm 3 \mathrm{ml} . / \mathrm{min}$. The MBP during hypotension ${ }_{0}$ (average of values taken every 15 minutes) was 


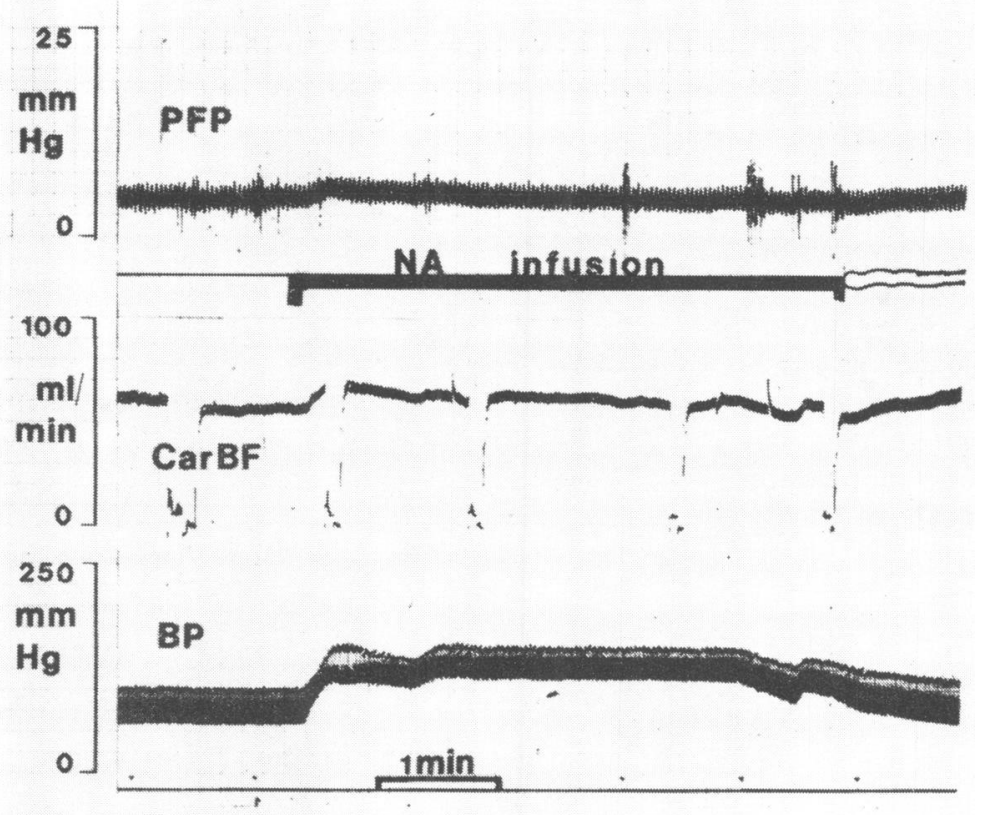

FIG. 3. Effect of noradrenaline (NA) infusion on blood pressure (BP), internal carotid blood flow (CarBF) and posterior fossa pressure (PFP) before the period of hypotension. Zero recalibration interrupts the CarBF trace. Autoregulation judged to be present as large changes in CarBF and PFP did not occur when BP was raised.

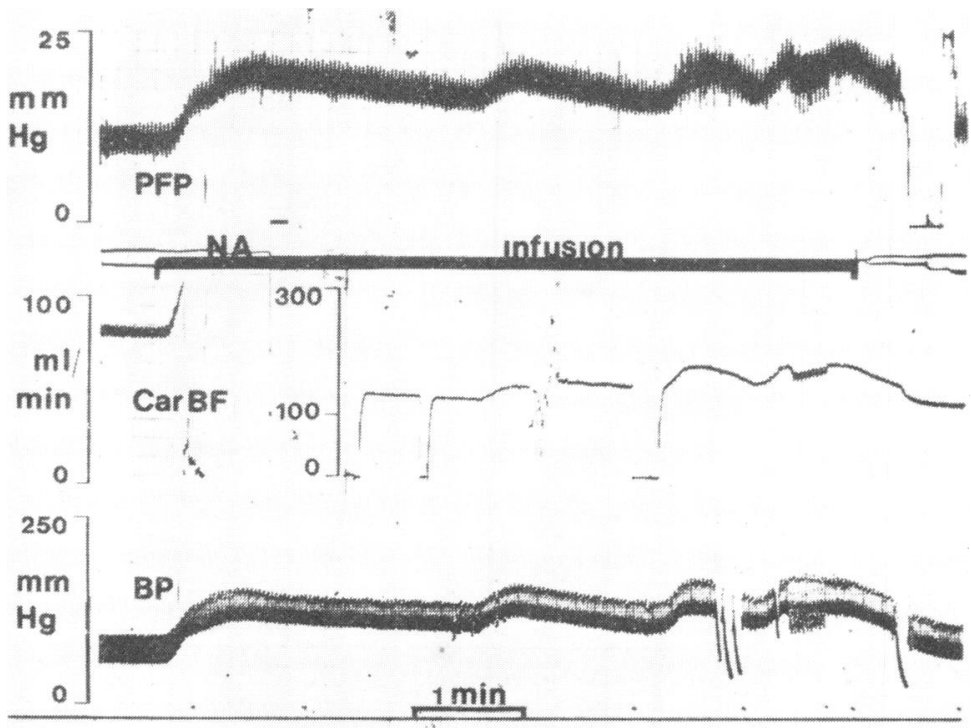

FIG. 4. Effect of nor-

adrenaline (NA) infusion on blood pressure (BP), internal carotid blood flow (CarBF) and posterior fossa pressure (PFP) after the period of hypotension. Zero recalibration and change of scale interrupts the CarBF trace. Autoregulation is absent as large changes of CarBF and PFP occurred when $B P$ was raised. 
$38 \%$ of the control-that is, $33 \pm 1 \mathrm{mmHg}-$ which corresponded to a systolic blood pressure of $45 \pm 3 \mathrm{mmHg}$, and CarBF was $20 \pm 2 \mathrm{ml} . / \mathrm{min}$, $44 \%$ of control (range $30-68 \%$ ) at this blood pressure. Arterial $\mathrm{PO}_{2}$ was higher during and after hypotension $(\mathrm{P}<0.01)$ and arterial $\mathrm{PCO}_{2}$ was virtually unchanged throughout (Table 2). A significant metabolic acidosis was detected in the arterial blood in the post-hypotensive period. Satisfactory EEG records were obtained from seven experiments. All baboons except no. 10 showed periods of electrical silence or burstsuppression during hypotension. All grades of EEG were found below MBP $40 \mathrm{mmHg}$, but neither electrical silence nor burst-suppression was seen above this pressure or above CarBF $35 \mathrm{ml} . / \mathrm{min}$.
TABLE 3

RESPONSE OF CAROTID VASCULAR RESISTANCE (CVR) TO MEAN BLOOD PRESSURE (MBP) ELEVATION BY NORADRENALINE (NA) INFUSION BEFORE AND AFTER HYPOTENSION

\begin{tabular}{|c|c|c|c|c|c|c|c|}
\hline \multirow{2}{*}{$\begin{array}{l}\text { Expt. } \\
\text { no. }\end{array}$} & & \multicolumn{3}{|c|}{ Before hypotension } & \multicolumn{3}{|c|}{ After hypotension } \\
\hline & & Control & $N A$ & $\Delta \%$ & Control & $N A$ & $\Delta \%$ \\
\hline \multirow[t]{2}{*}{6} & CVR & 1.20 & 1.95 & +63 & 0.69 & 0.75 & +8 \\
\hline & MBP & 73 & 123 & +68 & 78 & 119 & +52 \\
\hline \multirow[t]{2}{*}{7} & CVR & 2.53 & $2 \cdot 35$ & -7 & $2 \cdot 35$ & 1.60 & -32 \\
\hline & MBP & 75 & 105 & +40 & 73 & 105 & +44 \\
\hline \multirow[t]{2}{*}{8} & CVR & $1 \cdot 35$ & $1 \cdot 15$ & -15 & 1.41 & $1 \cdot 14$ & -19 \\
\hline & MBP & 62 & 100 & +61 & 65 & 99 & +52 \\
\hline \multirow[t]{2}{*}{9} & CVR & 1.48 & $2 \cdot 34$ & +58 & $1 \cdot 20$ & 0.95 & -21 \\
\hline & MBP & 92 & 138 & +50 & 86 & 138 & +60 \\
\hline \multirow[t]{2}{*}{10} & CVR & 1.69 & $2 \cdot 50$ & +48 & 1.60 & 2.02 & +26 \\
\hline & MBP & 75 & 115 & +53 & 75 & 115 & +53 \\
\hline \multirow[t]{2}{*}{11} & CVR & $2 \cdot 20$ & $2 \cdot 88$ & +31 & 1.74 & 1.98 & +14 \\
\hline & MBP & 68 & 112 & +65 & 68 & 111 & +63 \\
\hline
\end{tabular}

Values are CVR units, $\mathrm{mmHg}$ and percentage changes in six animals (see Fig. 2).

TABLE 4

CEREBRAL OXYGEN UPTAKE BEFORE AND DURING HYPOTENSION; BASED ON OXYGEN SATURATION (*) AND DIRECT OXYGEN CONTENT $(\dagger)$ MEASUREMENTS

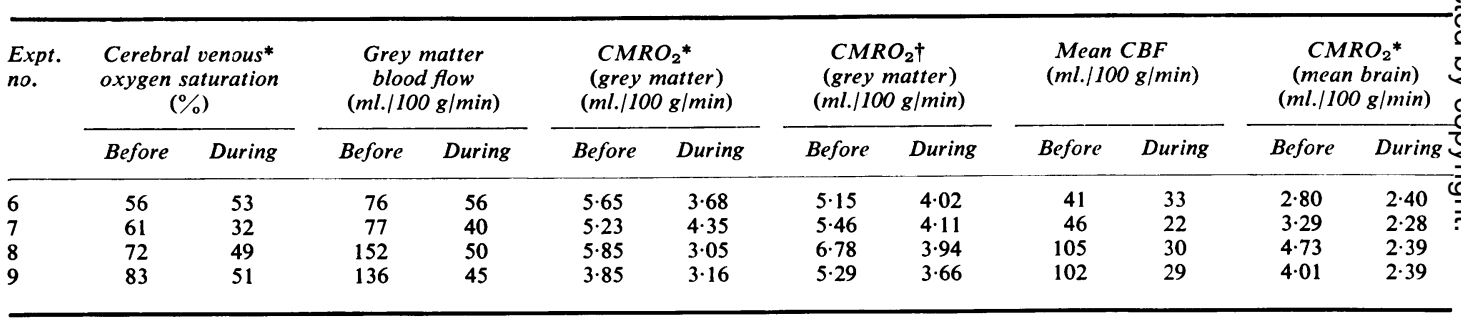

Values are means for each animal.

TABLE 5

CEREBRAL OXYGEN UPTAKE BEFORE AND DURING HYPOTENSION, BASED ON OXYGEN SATURATION (*) AND DIRECT OXYGEN CONTENT ( $\dagger$ ) MEASUREMENTS

\begin{tabular}{|c|c|c|c|}
\hline & \multicolumn{3}{|c|}{ Hypotension } \\
\hline & Before & During & $P$ \\
\hline $\begin{array}{l}\text { Cerebral* venous oxygen } \\
\text { saturation }(\%)\end{array}$ & $68 \cdot 0 \pm 6 \cdot 0$ & $46 \cdot 2 \pm 4 \cdot 8$ & $<0.05$ \\
\hline $\begin{array}{l}\mathrm{CMRO}_{2} * \text { (grey matter flow) } \\
(\mathrm{ml} .) 100 \mathrm{~g} / \mathrm{min})\end{array}$ & $5 \cdot 15 \pm 0.45$ & $3 \cdot 56 \pm 0.30$ & $<0.025$ \\
\hline $\begin{array}{l}\mathrm{CMRO}_{2} \dagger \text { (grey matter flow) } \\
(\mathrm{ml} . / 100 \mathrm{~g} / \mathrm{min})\end{array}$ & $5.67 \pm 0.38$ & $3.93 \pm 0 \cdot 10$ & $<0.01$ \\
\hline $\begin{array}{l}\mathrm{CMRO}_{2} *(\mathrm{mean} \\
(\mathrm{ml} . / 100 \mathrm{~g} / \mathrm{min})\end{array}$ & $3.71 \pm 0.42$ & $2 \cdot 37 \pm 0 \cdot 28$ & $<0.025$ \\
\hline $\begin{array}{l}\text { End-tidal halothane } \\
(\mathrm{v} / \mathrm{v} \%)\end{array}$ & $0.31 \pm 0.02$ & $1 \cdot 16 \pm 0 \cdot 14$ & \\
\hline
\end{tabular}

Values are means \pm SEM. P derived from paired $t$ tests.
TABLE 6

CSF ACID-BASE MEASUREMENTS

\begin{tabular}{|c|c|c|c|}
\hline & \multicolumn{3}{|c|}{ Hypotension } \\
\hline & Before & During & After \\
\hline $\operatorname{CSF}(\mathrm{pH})$ & $\begin{array}{r}7 \cdot 305 \\
\pm 0.005\end{array}$ & $\begin{array}{r}7 \cdot 260 \dagger \\
\pm 0.004\end{array}$ & $\begin{array}{r}7 \cdot 270^{*} \\
\pm 0.011\end{array}$ \\
\hline $\begin{array}{l}\mathrm{CSF} \mathrm{PCO}_{2} \\
(\mathrm{mmHg})\end{array}$ & $\begin{array}{r}43 \cdot 0 \\
\pm 2 \cdot 0\end{array}$ & $\begin{array}{l}48 \cdot 8^{*} \\
\pm 2 \cdot 9\end{array}$ & $\begin{array}{r}48 \cdot 2 \\
\pm 3 \cdot 8\end{array}$ \\
\hline $\begin{array}{l}\mathrm{CSF} \mathrm{HCO}_{3} \\
(\mathrm{mEq} / \mathrm{l} .)\end{array}$ & $\begin{array}{r}20 \cdot 3 \\
\pm 0 \cdot 7\end{array}$ & $\begin{array}{r}20 \cdot 5 \\
\pm 1 \cdot 3\end{array}$ & $\begin{array}{r}20 \cdot 7 \\
\pm 1 \cdot 2\end{array}$ \\
\hline $\begin{array}{l}\text { CSF-arterial } \triangle \mathrm{PCO}_{2} \\
(\mathrm{mmHg})\end{array}$ & $\begin{array}{r}3 \cdot 3 \\
\pm 1 \cdot 8\end{array}$ & $\begin{array}{r}8 \cdot 5^{*} \\
\pm 1 \cdot 1\end{array}$ & $\begin{array}{r}5 \cdot 0 \\
\pm 0.9\end{array}$ \\
\hline
\end{tabular}

Values are means \pm SEM

$* \mathbf{P}<0.025$.

$+\mathbf{P}<0.01$, derived from paired $t$ tests. 
In the first five experiments cerebral blood flow, measured by both methods, increased above control levels in those animals which regained a mean blood pressure $>70 \mathrm{mmHg}$ after the period of hypotension (Fig. 1). In the subsequent six experiments autoregulation was tested before and after hypotension. Figure 2 shows that in animals $6,9,10$, and 11 the calculated carotid vascular resistance $(\mathrm{CVR}=\mathrm{MBP} / \mathrm{CarBF})$ rose when the blood pressure was elevated by intravenous NA infusion during the control period and autoregulation was considered to be present. When autoregulation was again tested after the period of hypotension there was either no increase of CVR with blood pressure elevation or a lesser increase than control. There was, therefore, loss or impairment of autoregulation after deliberate hypotension. Table 3 gives the data on which Fig. 2 is based and the difference in percentage change of CVR, before and after hypotension, is statistically significant $(P<0.05$, $n=6$ ). Xenon clearance (initial slope) confirmed that CBF increased passively with blood pressure elevation in the post-hypotensive period.

The relationship between blood pressure, CarBF, and posterior fossa pressure during the control period in one animal which demonstrated autoregulation is shown in Fig. 3. A fifty per cent elevation of blood pressure raised CarBF initially and posterior fossa pressure minimally, but three minutes after the start of NA infusion CarBF was only $2 \mathrm{ml} . / \mathrm{min}$ higher than at normotension. In this animal after deep halothane hypotension a similar rise of blood pressure increased CarBF by $85 \%$ and intracranial pressure by almost $100 \%$, showing loss of autoregulation (Fig. 4).

Tables 4, 5, and 6 contain results from the animals in which Xenon clearance, oxygen uptake, and CSF measurements were made. Mean cerebral and grey matter blood flow, cerebral venous oxygen saturation, and cerebral oxygen uptake decreased during deep halothane hypotension (Table 4). The fall in cerebral oxygen consumption was statistically significant whether it was calculated from the oxygen saturation or direct oxygen content measurements and grey matter or mean cerebral blood flow. End tidal halothane during hypotension was $1 \cdot 16 \pm 0 \cdot 14$ $\mathrm{v} / \mathrm{v} \%$ (Table 5).

There was no evidence of a CSF metabolic acidosis during hypotension (Table 6) or afterwards, at which time there was a metabolic acidosis in the arterial blood. The increases in the CSF $\mathrm{PCO}_{2}$ and CSF-arterial $\mathrm{PCO}_{2}$ difference during hypotension were statistically significant and reflect the finding that the fall of CBF was greater than the decrease of cerebral oxygen uptake.

\section{DISCUSSION}

Freeman and Ingvar (1968) have demonstrated cerebral hyperaemia and loss of autoregulation after haemorrhagic hypotension in cats with exposed cerebral cortex and have postulated that these findings indicate cerebral tissue acidosis resulting from inadequate cerebral perfusion during the period of hypotension. The severity of hypotension used by these workers was greater than that employed clinically and indeed was similar to the blood pressure level shown by Brierley et al. (1969) to produce ischaemic damage in boundary zones. In the present study blood pressure was reduced to the lowest levels employed clinically by a technique which is clinically acceptable and which, because it involves deep anaesthesia with halothane, might be expected to protect the brain from ischaemia through depression of cerebral oxygen uptake.

Certainly during deep halothane anaesthesia cerebral oxygen uptake was $30 \%$ below the values obtaining during light halothane anaesthesia, a finding which confirms the earlier work of McDowall (1967) in dogs. The $\mathrm{CMRO}_{2}$ calculations were based on sagittal sinus blood oxygen measurements. Häggendal and Nörback (1966) have shown that the washout curve of krypton obtained from venous blood from the dog's sagittal sinus is 'practically uniexponential and represents cerebral cortical flow with a very small amount of activity from other tissues with slower perfusion'. It may be valid, therefore, to use grey matter flow together with sagittal sinus oxygen measurements to calculate $\mathrm{CMRO}_{2}$ in the baboon. We have, however, also calculated $\mathrm{CMRO}_{2}$ on the basis of mean cerebral blood flow values. $\mathrm{CMRO}_{2}$ decreased significantly during halothane hypotension whether it was calculated from grey matter or mean cerebral blood flow or oxygen saturation or direct oxygen content measurements. 
Despite this depression of $\mathrm{CMRO}_{2}$, definite changes in cerebral vascular control were demonstrated after deep halothane hypotension. These changes consisted of loss or impairment of autoregulation in response to blood pressure elevation. This finding might indicate that cerebral ischaemia occurred during the hypotensive period and resulted in the production of cerebral tissue acidosis. However, if cerebral ischaemia did occur in the present experiments it was not evidenced by changes in CSF bicarbonate. The findings of Zwetnow (1968) would indicate that a tissue acidosis should have been represented in the cisternal CSF by the end of the two hours during which hypotension was present. Nilsson and Siesjö (1971), who also produced hypotension by deep halothane anaesthesia but together with positive end-expiratory pressure in rats, showed only a moderate increase in anaerobic glycolysis with well-maintained high energy reserves - a finding supported by the absence of CSF metabolic acidosis in the present study.

Another factor against implicating cerebral ischaemia as the cause of the loss of autoregulation is the observation that values for cerebral venous oxygen saturation were well-maintained throughout the period of hypotension. However, caution is necessary in interpreting cerebral venous oxygen measurements in view of the work of Eklöf and Siesjö (1971) who showed that in ischaemic rat brain high energy reserves fell at a cerebral venous $\mathrm{PO}_{2}$ well above the critical value established for hypoxaemia by Schneider (1963). Cerebral venous oxygen measurements in patients during hypotensive anaesthesia made by Eckenhoff et al. (1963) and Salem et al. (1970) may therefore not be complete proof of adequate cerebral perfusion.

A further possibility is that the cerebral vasodilator halothane may itself impair autoregulation. Against this, however, is the very adequate autoregulation which was present in all but two animals during the control period when endtidal halothane was $0.31 \mathrm{v} / \mathrm{v} \%$ The depth of halothane anaesthesia in the post-hypotensive period was similar to that during the control measurements as judged by EEG and end-tidal halothane $(0.4 \mathrm{v} / \mathrm{v} \%-3$ observations $)$. This mechanism cannot therefore be responsible for the posthypotensive loss of autoregulation.
This loss of autoregulation may then have $\frac{\mathbb{D}}{\frac{C}{二}}$ been due to a degree of tissue ischaemia too subtle to be reflected in measurements of large cavity CSF acid base or sagittal sinus venous oxygen.

During the period of hypotension it was noted that cerebral blood flow was very sensitive to. slight changes in the level of blood pressure. $\overrightarrow{\vec{F}}$ Furthermore, there was variation from one $\frac{\text { ? }}{0}$ animal to another in the reduction in blood flow $\frac{O}{\partial}$ produced by the same reduction in pressure. $\frac{\bar{\sigma}}{2}$ Therefore not all animals were exposed to the $\underset{\alpha}{\circ}$ same level of cerebral ischaemia. Another variable was the amount of surgery and blood $\stackrel{\omega}{\vec{O}}$ loss which occurred before the induction of halothane hypotension; in two animals these $\vec{\omega}$ latter factors were sufficient themselves to abolish autoregulation before the period of hypotension. On the other hand, the animal which had least surgery and presumably, then, least blood loss o and which showed only a $30 \%$ fall in the blood flow during hypotension was the only animal show some partial maintenance of autoregulatiog 을 after hypotension.

EEG monitoring has been used clinically t assess the adequacy of cerebral perfusion ang our results may support this approach, sine periods of electrical silence or burst-suppressio were seen in all animals save the one which rètained partial autoregulation. These low activity EEG patterns were not seen above a mean blood pressure of $40 \mathrm{mmHg}$ or an internal carotid blood flow of $35 \mathrm{ml} . / \mathrm{min}$.

The importance of loss of autoregulation lies in the increase of intracranial pressure produced by a rise of blood pressure and in the possibility that damage to the blood brain barrier and cerebral oedema may occur when the capillary bed is not protected from sudden changes in intravascular pressure (Häggendal and Johansson, 1971/72). Patients who have undergone major neurosurgery may have areas of impaired autoregulation in the postoperative period in view of Brock's (1968) experimental findings. Our results suggest that, even without direct surgical manipulation of the brain, deep halothane hypotension may lead to loss of autoregulation. The clinical implications of loss of autoregulation are not at this time clear, but it would seem prudent to avoid sudden increases 
in blood pressure in the period after the employment of deliberate hypotension.

NPK was in receipt of a Medical Research Council grant which also supported the costs of this study. NJC was in receipt of a Commonwealth Medical Fellowship sponsored by the British Council and a grant from the Board of Governors of the United Leeds Hospitals. The authors wish to thank Mr. B. G. Gough, Mr. M. Standen, Mr. M. Maher, and Mr. A. G. Russell for technical assistance and Mrs. S. Barlow for secretarial help.

\section{REFERENCES}

Brierley, J. B., Brown, A. W., Excell, B. J., and Meldrum, B. S. (1969). Brain damage in the rhesus monkey resulting from profound arterial hypotension. I. Its nature, distribution and general physiological correlates. Brain Research, 13, 68-100.

Brock, M. (1968). Regional cerebral blood flow (rCBF) changes following local brain compression in the cat. Scandinavian Journal of Laboratory and Clinical Investigation, 22, Suppl. 102, XIV: A.

Eckenhoff, J. E., Enderby, G. E. H., Larson, A., Davies, R., and Judevine, D. E. (1963). Human cerebral circulation during deliberate hypotension and head-up tilt. Journal of Applied Physiology, 18, 1130-1138.

Eklöf, B., and Siesjö, B. K. (1971). Cerebral blood flow and cerebral energy state. Acta Physiologica Scandinavica, 82, 409-411.

Enderby, G. E. H. (1972). Brickbats and bouquets. Correspondence in Survey of Anesthesiology, 16, 276.
Freeman, J., and Ingvar, D. H. (1968). Elimination by hypoxia of cerebral blood flow autoregulation and EEG relationship. Experimental Brain Research, 5, 61-71.

Häggendal, E., and Johansson, B. (1971/72). Pathophysiological aspects of the blood brain barrier change in acute arterial hypertension. European Neurology, 6, 24-28.

Häggendal, E., and Norbäck, B. (1966). Effect of blood pressure and hematocrit on cerebral metabolic rate of oxygen. Acta Chirurgica Scandinavica, Suppl. 364, 23-31.

Linden, R. J., Ledsome, J. R., and Norman, J. (1965). Simple methods for the determination of the concentrations of carbon dioxide and oxygen in blood. British Journal of Anaesthesia, 37, 77-88.

Mayrhofer, O. K. (1971). Comment in Survey of Anesthesiology, 15, 230-231.

McDowall, D. G. (1967). The effects of clinical concentrations of halothane on the blood flow and oxygen uptake of the cerebral cortex. British Journal of Anaesthesia, 39, 186196.

Nilsson, L., and Siesjö, B. K. (1971). The effect of deep halothane hypotension upon labile phosphates and upon extra- and intracellular lactate and pyruvate concentrations in the rat brain. Acta Physiologica Scandinavica, 81, 508516.

Salem, M. R., Kim, Y., and Shaker, M. H. (1970). The effect of alteration of inspired oxygen concentration on jugularbulb oxygen tension during deliberate hypotension. Anesthesiology, 33, 358-361.

Schneider, M. (1963). Critical blood pressure in the cerebral circulation. In Selective Vulnerability of the Brain in Hypoxaemia, pp. 7-20. Edited by J. P. Schadé and W. H. McMenemy. Blackwell: Oxford.

Zwetnow, N. (1968). Effects of intracranial hypertension: acid base changes and lactate changes in CSF and brain tissue. Scandinavian Journal of Laboratory and Clinical Investigation, 22, Suppl. 102, IIID. 